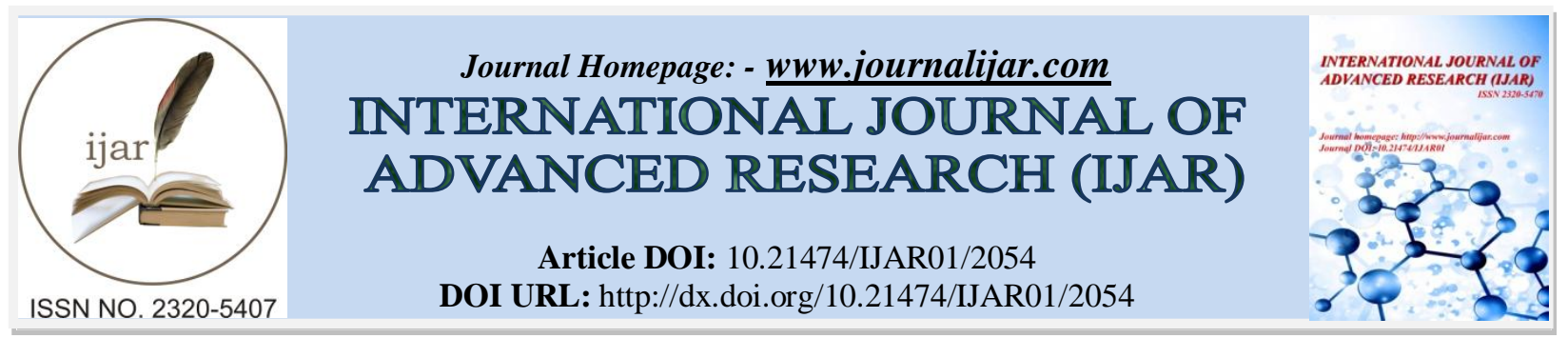

RESEARCH ARTICLE

\title{
SOCIOLOGICAL ANALYSIS OF ICT ENTERPRISES AND SOCIO-ECONOMIC CONDITION OF RURAL PEOPLE IN NIGERIA.
}

\author{
Jonathan Akwagiobe Ukah ${ }^{1}$, Francis Abul Uyang ${ }^{2}$ and Joy Aboli Ejeje ${ }^{2}$.
}

1. Department of Psychology, Sociology and Criminology Federal University Ndufu-Alike, Ikwo P.M.B. 1157 Ebonyi State, Nigeria.

2. Department of Sociology, University of Calabar, P.M.B. 1115, Calabar, Nigeria.

\section{Manuscript Info}

[........................

Manuscript History

Received: 20 September 2016

Final Accepted: 22 October 2016

Published: November 2016

Key words:-

Socioeconomic, ICT, Income level, Jobs creation and rural people.

\section{Abstract}

This paper examined ICT and socio-economic condition of rural people in Nigeria. Rural communities in Nigeria are characterized by poverty due to poor income level and lack of job opportunities. This situation is worrisome and often pushes these disadvantaged groups into unlawful activities such as theft and arm robbery in order to make a living. A survey design was adopted to capture the wide spread variables involved in the study. The sampled population size was 500 which was determined by Taro Yamane's formula. Questionnaire was used to gather the data and was validated by two researchers and the reliability test of the instrument was 0.76 . Two hypotheses were formulated and tested with chi-square statistics and the result revealed that there is a significant relationship between ICT and income level of rural people. Also, there is a significant relationship between ICT and jobs creation in rural area. It has been recommended that Government should strengthen ICT facilities in rural communities. Government need to identify the ICT needs gap and fill them and putting measures in place to maintain existing ICT infrastructures and also use ICT skills acquisition as a means of reducing poverty in rural communities. It has been concluded that Information and communication technology remains a potent tool for enhancement of income level and creation of job opportunities for rural dwellers. The study has confirmed that there is a significant relationship between ICT and income level and jobs creation in rural communities in Nigeria.

Copy Right, IJAR, 2016,. All rights reserved.

\section{Introduction:-}

Rural development in Nigeria has attracted a lot of attention from NGOs, development partners, government, and other community-based organizations in recent times, because of its many challenges. These challenges include entrenched poverty, lack of employment opportunities, poor income level and lack of ICT facilities to enhance their educational status. 
The severity of the problem has necessitated the formulation of Information and Communication Technology and other development policies towards ameliorating the challenges. Digital divide relates to the disparities in ICT use between people living in urban centres and rural communities in Nigeria which are wide and require a policy direction to narrow the gap. As part of a strategic plan to narrow the gap, the Obasanjo administration in 2001 established the National Information Technology Development Agency (NITDA) to serve as a bureau for the implementation of national policy on Information Technology (Emadoye 2002). NITDA had developed national Information and Communication Technology (ICT) Strategic Plan with a timeline of 2010-2015. The implementation of the plan is ongoing in sectors, such as education, agriculture, health, governance and the judiciary. Other areas are human capital development and national security, among others, which have propelled the level of development in the ICT sector.

Thioune (2003) explains that for the past two decades most developed countries have witnessed significant changes that can be traced to ICTs. These multi-dimensional changes have been observed in almost all aspects of life: economics, education, communication, and travel. This implies that ICTs penetration has the potency to trigger development. According to Nigerian Economic Survey Report (2003) in Nigeria, a large number of economically active poor people are known to reside in rural areas. The feelings of the researcher towards the plight of the rural people is necessitated by the inability of the government ( Federal, State and Local) to judiciously manage resources to better the quality of lives of the rural people. ICTs infrastructures are over concentrated in cities leading to digital poverty in rural communities. These may have been responsible for rural urban migration for greener pastures.

This study will be of theoretical and practical significance in many ways: Theoretically, the study will lead to the formulation of new theories that would expand the theoretical horizon as well as making meaningful contributions to intellectual discourse on ICT and rural development in Nigeria. The findings from this study will also add to the existing literature on ICT and rural development in Nigeria. This paper therefore seeks to provide answers to the following questions. How ICT enterprises do enhanced the income level of the rural people, does ICT contribute to jobs creation in rural communities? and what measures need to be put in place in order to improve the income level of the rural people.

\section{Statement of the problem:-}

Rural communities in Nigeria are characterized by poverty due to poor income level and lack of job opportunities. This is due to the absence of industries including ICT facilities and lopsided development programmes in rural communities in Nigeria, job opportunities have become a mirage to the people with the corresponding consequences of poor living condition, hardship and unproductive life style. This situation is worrisome and often pushes these disadvantaged groups into unlawful activities such as theft and arm robbery in order to make a living

\section{General objective:-}

The general objective is to assess the impact of ICT businesses on the development of Obudu LGA.

\section{Specific objectives:-}

1. To assess the relationship between ICT businesses and job creation in rural areas in Nigeria.

2. To analyze ICT enterprises and enhancement of income level of rural people in Nigeria.

\section{Research questions:-}

1. How ICT enterprises do enhanced the income level of the rural people?

2. Is there any relationship between ICT enterprises and jobs creation in rural communities?

3. What measures need to be put in place in order to improve the income level of the rural people?

\section{Research hypotheses:-}

Hypothesis one: (Ho): There is no significant relationship between ICT enterprises and income level of rural people Hypothesis two: (Ho): There is no significant relationship between ICT enterprises and jobs creation in rural communities

\section{Review of related literature:-}

\section{ICT and Income Level of rural People:-}

There are indications to show the enormous benefits of ICT in area of improvement of income level through ICT jobs opportunities. Development in Nigeria depends on the country's capacity to create wealth to significantly 
reduce poverty and to raise the capacity of its citizens to create wealth at a sustainable level. A lot of youths in Nigeria have acquired ICT skills and are now self employed. In June 1996, the United Nations Commission on Science and Technology Development (UNCSTD) in collaboration with IDRC proposed five development indicators that focused on the improvement of the quality of life: education, health, income, governance, and technology (Crede and Mansell, 1998). If we consider these five as key indicators of development for Nigeria, ICTs can be socially beneficial only if they contribute to poverty eradication (higher income), improved health and education, better use and more equitable sharing of resources, and raising participation in the decision-making processes.

Adedoyin (2004) claims that it is widely known and recognized that sustained high level of agricultural and rural transformation programmes to ensure food self-sufficiency cannot be attained without effective strategies which requires the application of Information Communication Technology (ICT). In order to attain the required growth in the rural and agricultural sector, the rural community must not be left behind in the effort in creating a knowledgeable society in which ICT becomes the key to socio-economic development (Tap Bin Sallah, 2004).Ajayi (1998) suggests that in order to make Nigeria a key player in the information society through the use of ICTs as the engine for sustainable development and global competitiveness, the Nigerian government has the following goals for the use of ICTs: Education, Creation of wealth, Poverty eradication, Job creation and Global competitiveness.

\section{ICT and Jobs creation:-}

Information communication technology is gradually penetrating the rural communities in Nigeria. Communication is becoming easier and computer information technology is spreading widely. Presently, youths in rural communities engage themselves in ICT profitable ventures such as pay phone calls, sales of recharge cards, Computer operators, GSM repairs, Cyber Cafes, Sales of GSM handset and Telecommunication accessories. Awake (2009) opines that cell phones, Computers and Televisions have found their way into every corner of the world even crossing the divide between rich and poor and have become a part of life for many. Similarly, Yahaya (2008) observes that the use of information by rural communities determines their level of awareness, progress, development and success in life. The implementation of the e-wallet system by the former president of Nigeria Good Luck Jonathan in 2014 to boost the agricultural practice in Nigeria was a welcome development. ICT can be useful in agricultural sector through gathering and dissemination of information that could help farmers and agricultural extension workers. Edobong (2016) was of the similar view that ICT solutions can increase efficiencies and improve competitive dynamics in job creation through agriculture, which can raise agricultural productivity and this can empower agricultural producers by improving their marketing capabilities especially for small holder farmers. The need to depend on ICT in advancing rural communities in Nigeria should be given a top priority.

According to Okiy (2003), rural development and information is an important ingredient in development process. An effective Information and Communication Technology service in rural communities enhances development despite the conditions of the rural dwellers. If meaningful development must be felt in rural communities in this $21^{\text {st }}$ century, attention must be given to ICT development in rural communities in Nigeria. About 75 to 80 per cent of people in developing countries live in rural areas. Inyang (2013) pointed out that probably the best advantage of information technology is the creation of new interesting job. He further explains that computer programmers, system analyzers, hardware and software developers are just some of the many new employment opportunities created with the help of IT

\section{Theoretical framework:- Modernization Theory:-}

Marquis de Condorcet, a French philosopher, is the originator of the theory with the concept of technological advancements and economic changes. The theory of modernization was popularized by David MacLean in the 1950s and 1960s. This is a socio-cultural theory, commonly used as development theory, which highlights the positive role played by the developed world in modernizing and facilitating sustainable development in underdeveloped nations.

It combines the previous theories of socio-cultural evolution with practical experiences and empirical research. The theory states that: Western countries are the most developed, and rest of the world (mostly former colonies are of the earlier stages of development), will eventually reach the same level as the western world. Developmental stages progress from the traditional societies to developed ones. Third world countries have fallen behind with their social progress and need to be directed on their way to becoming more advanced. It stresses the modernization factor. 
Those societies are simply trying to emulate the most successful societies and cultures. It also states that it is possible to do so, thus supporting the concepts of social engineering and that the developed countries can help those less developed, directly or indirectly.

Information and Communication Technology diffused into the developing countries. Internet started in the United State and also, the first generations of computers were manufactured in the 1940s in the western societies. The origin of most communication devices is traceable to the developed world. With globalization and advancement of knowledge, these devices are now available in various parts of the Third World countries, example Nigeria. Most of the telecommunication operators in Nigeria are foreign investors. It is observed that with their operation here, job opportunities are created for people, communication becomes easy, the countries earn revenue from taxation and there is also a provision of education support services.

\section{Methodology:-}

The area of study covers Obudu Local Government Area of Cross River State, Nigeria.. Obudu Local Government Area is bounded to the North by Vandikia Local Government Area of Benue State, to the east by Obanliku Local Government Area of Cross River State, to the south by Boki Local Government, to the west by Bekwarra Local Government Area of Cross River State. Obudu Local Government Area has an area of 300.44 square kilometer. The population of Obudu according to population census of 2006 is 160106 with the male population of 83479 and female population of 76627 respectively. The major languages spoken by Obudu are Bette and Utugwang.

The following rural communities constitute the population of the study which includes Abonkep, Bebuagam, Bebuabong, Ohong, Kakum, Bebuawan and Utugwang.The rationale for the selection of these communities is predicated on the fact that they harbor ICT facilities. The population size for the study was 400 which were determined by the use of Taro Yamane's formula. Purposive sampling technique was used to select the communities and ICT vendors. This is because the technique afforded the researcher an opportunity to capture all the communities where ICT centers are found. Arising from this, all the respondents are involved in ICT use in rural communities including both male and female from the age of 20 years and above. The hypotheses were tested with chi-square statistics at .05 significant levels.

A survey design was adopted for this study. This was necessitated by the attempt to capture the wide spread variables in the study. Questionnaire was the instrument used to gather data which were analysed statistically. The reliability of the instrument was tested ensure its consistency and the coefficient value was 0.76 indicating that, the instrument was reliable for the study..

\section{Results:-}

Chi-square test is a statistical technique the researcher employed to test the hypotheses. This chi-square is based on the difference between frequency of occurrence of observation in the given sample and the expected frequency obtained between the observed and expected frequencies. The decision to reject or accept the null hypothesis is dependent on the calculated chi-square value if it is greater or less than the table value, with 0.5 level of significance and the degree of freedom equal to ( $r-1)(\mathrm{c}-1)$.

The formula for calculating the chi- square is given as $\mathrm{X}^{2}=\left(\frac{\text { of-ef })^{2}}{\mathrm{Ef}}\right.$

Table 1:- Hypothesis three: Contingency table of $\mathrm{X}^{2}$ showing the relationship between ICT enterprises and the income level of the people of Obudu Local Government Area

\begin{tabular}{|l|l|l|l|l|l|}
\hline Cell & Of & Ef & $($ o-e $)$ & $(\text { o-e })^{2}$ & $(\text { o-e })^{2} /$ ef \\
\hline 1 & 300 & 62.37 & 237.63 & 56467.99 & 905.37 \\
\hline 2 & 101 & 21.00 & 80.00 & 6400.33 & 304.81 \\
\hline 3 & 80 & 16.63 & 63.37 & 4015.50 & 241.43 \\
\hline & $\mathrm{X}^{2}$ Calculated value & $=$ & & & 1451.61 \\
\hline
\end{tabular}

$\mathrm{df}=2$

Source: Author's fieldwork, 2016 
Null hypothesis $\left(\mathrm{H}_{0}\right)$ : There is no significant relationship between ICT enterprises and the income level of the people of Obudu Local Government Area in Cross River State.

Alternate hypothesis $\left(\mathrm{H}_{1}\right)$ : There is a significant relationship between ICT enterprises and the income level of the people of Obudu Local Government Area in Cross River State.

The independent variable is ICT while the dependent variable is income level. From table1, it was revealed that the calculated ch-square is 1451.61 with the degree of freedom of 2.

\section{Decision:-}

Since the calculated value of $\mathrm{X}^{2}(1451.61)$ at degree of freedom of 2, and .05 level of significance is greater than the table value of 5.991, we therefore, refute the null hypothesis ( Ho ) and accept the alternate hypothesis ( H1 ) which states that there is a significant relationship between ICT and income level of the people of Obudu Local Government Area of Cross River State.

Table 2:- Hypothesis two: Relationship between availability of ICT enterprises and creation of job opportunities in Obudu Local Government Area

\begin{tabular}{|l|l|l|l|l|l|}
\hline Cells & O & E & (o-e) & (o-e)2 & (o-e)2/ef \\
\hline 1 & 200 & 41.67 & 158.33 & 25069.44 & 601.67 \\
\hline 2 & 160 & 33.33 & 126.67 & 16044.44 & 481.33 \\
\hline 3 & 50 & 10.42 & 39.58 & 1566.84 & 150.42 \\
\hline 4 & 25 & 5.21 & 19.79 & 391.7101 & 75.21 \\
\hline 5 & 31 & 6.46 & 24.54 & 602.2934 & 93.26 \\
\hline 6 & 14 & 2.92 & 11.08 & 122.8403 & 42.12 \\
\hline
\end{tabular}

Source: Author's fieldwork, 2016

Calculated X2 $=1444.00$

Df $=2$

Null hypothesis (Ho): $\quad$ There is no significant relationship between availability of ICT businesses and creation of job opportunities in Obudu Local Government Area.

Alternate hypothesis (H1): There is a significant relationship between availability of ICT businesses and creation of job opportunities in Obudu Local Government Area

Decision: Since the calculated value of $\mathrm{X}^{2}$ in table 2 is 1444.00 at degree of freedom of 2 , and .05 level of significance is greater than the table value of 5.991, we therefore, reject the null hypothesis ( Ho ) and accept the alternate hypothesis ( $\mathrm{H} 1$ ) which states that there is a significant relationship between availability of ICT businesses and creation of job opportunities in Obudu Local Government Area of Cross River State.

The independent variable is ICT business availability while the dependent variable is creation of job opportunities.

\section{Discussions:-}

In hypothesis one, in order to determine whether there exist any association between ICT and income level of the people of Obudu Local Government Area in Cross River State, the chi-square test was carried out in table 1 and it was revealed that ICT has a relationship with the income level of the respondents. Out of four hundred and eighty one respondents, three hundred and seventy six (376) representing 78.1 per cent agreed that there is a strong relationship between ICTs and income level in their communities, 101 respondents representing 21 per cent disagreed over the relationship while 4 respondents representing 0.8 gave no response over the issue.

The investigation further revealed that ICT has afforded the respondents the opportunities to generate income through sales of computer accessories, telephone accessories, recharge cards, computer parts and other consumables. From table1 it was revealed that 50 respondents representing 13.3 per cent were engaged in the sales of computer accessories, 57 respondents representing 15.2 per cent were engaged in sales of telephone accessories, 45 respondents representing 12.0 per cent were recharge cards dealers, 47 respondents representing 12.5 per cent deals on computer consumables while 176 respondents representing 46.9 per cent deals on other types of ICT businesses. Through these ICT business activities, 250 respondents representing 66.7 per cent agreed they earn monthly income from ICT businesses while 125 representing 33.3 claimed they have other sources of generating their income. 
In hypothesis two, in order to ascertain the relationship between ICT availability and creation of job opportunities in Obudu Local Government Area in Cross River State, the independent chi-square test was carried out in table 2 and it was revealed that availability of ICT has a relationship with job creation in rural communities. Some of the jobs that were identified to have been provided by ICT are: Digital studio, Cyber café, computer training, computer repairs, mobile phone repairs and others. The investigation shows that 75 respondents representing 20.0 per cent depend on digital studios business for their livelihood, 91 respondents representing 24.3 per cent acknowledged their involvement in typesetting businesses, 50 respondents representing 13.3 per cent confirmed the availability of cyber café jobs, 75 respondents representing 20.0 per cent attest for the availability of phone repairs services in their communities, 74 respondents representing 19.7 per cent recorded that computer training job opportunities are available while 10 respondents representing 2.7 per cent were of the view that there are other ICT jobs in their communities.

The implication of this is that ICT is seen as a hallmark for job creation in both urban and rural communities as a means of sustainable livelihood. The findings from this study corroborate with the findings of Obeng (2004) who indicated that ICT helps in poverty alleviation by generating or creating new jobs and investment opportunities, Also, Inyang (2013) pointed out that probably the best advantage of information technology is the creation of new interesting jobs. He further explains that computer programmers, system analyzers, hardware and software developers are just some of the many new employment opportunities created with the help of IT

\section{Recommendations:-}

1. Government should strengthen ICT facilities in rural communities. Government need to identify the ICT needs gap and fill them and putting measures in place to maintain existing ICT infrastructures

2. The government should see ICT services as a means of empowering the youths and creation of jobs opportunities. NGOs and government should establish ICT skill acquisition centres to provide the rural dwellers with free computer training most especially in areas like telephone repairs, computer operation, graphics and design, website development, programming and other areas that could be useful. After the training, the participant should be given financial assistance to enable them start their own businesses.

\section{Conclusion:-}

Information and communication technology remains a potent tool for enhancement of income level and creation of job opportunities for rural dwellers. The study has confirmed that there is a significant relationship between ICT and income level and jobs creation in rural communities in Nigeria.

\section{References:-}

1. Adedoyin S. F. (2004): Plentiful Agricultural Resources but Limited and agogical Tramsmission. Thirty Three Inaugural Lecture. Olabisi Onabanjo University, Ago- Ewoyi, Nigeria

2. Ajayi(2014): Compuworld Technology our World. Retrieved on 22 $2^{\text {nd }}$ March 2014 (Online: http://www.compuworld.com.ng/blog_read. aspx?read=4)

3. Crede, A., \& Mansell, R. (1998): Knowledge Societies. in a Nutshell: Information Technologies for Sustainable Development. Ottawa, Canada: IDRC.

4. Edobong A. (2016): ICT plays important role in job creation.Conference organized by on agriculture.Independent Newspapers Limited. Lagos (Retrieved from: http://dailyindependentnig.com/2014/08/ictplays-important-role-job-creation-saysakpabio-2/)

5. Emadoye, J.O. (2002): Information and Communication Technologies: Impact on governance, social and economic development. http://www.deltastate.gov.ng/ICT/impactongov.htm

6. Obeng, T. K. (2004): The Practical Application of ICT in Education. Results from a Worldwide Educational Assessment. Computer and Education; 37: $\quad$ 163-178

7. Okiy, R.B. (2003): Information for rural development: Challenge for Nigerian Rural Public Libraries. Library Review 52 (3):126-131.

8. Tap Bin Sallah, D. (2004): Rural Development in Malaysia Achievements and Challenges Journal of Rural Development 37(2):29-47.

9. Thioune, R.M.C. (2003): Information and communication technologies for development in Africa: Opportunities and challenges for community development. Volume 1. Ottawa: IDRC. (On line:.http://www.idrc.ca

10. Yahaya I. H. (2008): Information services for Rural Communities Development. Department of Library and Information Science, Faculty of Education, Bayero University Kano, Nigeria 